\title{
Morphological characterization of Coelogyne spp for germplasm conservation of orchids
}

\author{
Sri Hartati ${ }^{1 *}$ (D), Endang S. Muliawati ${ }^{1}$, Pardono Pardono ${ }^{1}$, Ongko Cahyono ${ }^{2}$, Ponco Yuliyanto ${ }^{3}$
}

10.1590/0034-737X201966040004

\begin{abstract}
Orchid is one of the ornamental plant that has a high aesthetic value. Efforts to increase the quality of orchids can be done by genetic improvement through crossing. The first step to success in orchid crossing requires information on morphological characters of the prospective parents. This study aims to determine the similarity of six species of natural Coelogyne spp based on qualitative morphological characters. Morphological characterization of 6 orchids was carried out based on 30 characters including stem, leaf, flower, pseudobulb, and rooting type. Cluster analysis was carried out with the NTSYSpc program version 2.02i with the UPGMA SimQual function method. The results showed that there were morphological diversities among the six Coelogyne spp on the character of the stem, pseudobulb, leaves, flowers and type of roots. Based on the dendrogram on $73 \%$ similarity, three major groups were obtained. The first group consisted of Coelogyne pandurata and Coelogyne rumphii, the second group was C. massangeana, C. mayeriana and C asperata, the third group was C. celebensis. Based on the morphological similarity of $87 \%$ there are two pairs of parents that have most successful chance to be crossed, C. pandurata with C. rumphii and C. mayeriana with C. asperata.
\end{abstract}

Keywords: character; cluster analysis; genetic improvement; morphological similarity.

\section{INTRODUCTION}

Orchidaceae is one of the largest family of plants, consisting of more than 25,000 species. Orchids are recognized as economically important commodities in the international flower industry, either as cut flowers or potted plants (Chase 2005; Hartati et al., 2017; Kuehnle, 2007). In adition to being used as an ornamental plant, several types of orchids have also been used as food or medicine (Luo et al., 2014).

The existence of natural orchids in their habitat is getting closer to extinction. Therefore increasing the genetic diversity of orchids by crossing is an important action to be taken.

Genetic relationship among cultivars is a very important factor for the success of a plant crossing program. Crossing between closely related species will increase the chances of success of crossing (Purwantoro et al. 2006). On the other hand the further the relationship between the parents, the smaller the success of the crossing (Julisaniah et al., 2008; Xu et al. 2010; Xue et al. 2010).

Genetic relationships of plants can be studied by using markers as a tool to carry out genetic characterization both molecular and morphological (Kartikaningrum et al., (2002). Morphological markers on plants include roots, stems, leaves, flowers, fruit, and so on. In orchids, the morphological characters of leaves and flowers are characters that are used as markers to distinguish between plant groups (Pangestu et al., 2014).

Rahayu \& Handayani (2008) stated that morphological characters are characters that are easily seen and not hidden

\footnotetext{
Submitted on October $17^{\text {th }}, 2018$ and accepted on July $29^{\text {th }}, 2019$

'Universitas Sebelas Maret, Faculty of Agriculture, Department of Agrotechnology, Surakarta, Central Java, Indonesia.

${ }^{2}$ Universitas Tunas Pembangunan, Faculty of Agriculture, Department of Agrotechnology, Surakarta, Central Java, Indonesia.

${ }^{3}$ Center for Plant Conservation-Bogor Botanical Gardens, Indonesian Institute of Sciences, Bogor West Java, Indonesia.

*Corresponding author: tatik_oc@yahoo.com
} 
characters, so the variations can be assessed quickly when compared with other characters. Moreover characterization of genetic diversity and relationship between Dendrobium orchids is very important for the sustainability of conservation and increasing the usefulness of plant genetic resources (Wang et al., 2009).

Several studies on morphological characterization of orchids have been carried out. One of them is a study to analyze the grouping and genetic relationship of 30 species of Dendrobium spp. in India by De et al. (2015). Nevertheless, the literature presenting the results of the study of the orchid population is still very low (Bhattacharyya, 2015). In addition, there are no research report that are related to the characterization of the Coelogyne, so information about the characteristics of Coelogyne spp is still very difficult to obtain.

Characterization can also be used as a basis for phylogenetic studies to determine crop diversification patterns (Freudenstein et al., 2015). In plant breeding, the results of characterization can be used as basic information about diversity and classification that can show the level and relationship between cultivars (Nandariyah, 2010). Characterization of genetic diversity and genetic relationships of orchids is very important for conservation of conservation and increasing the use of plant genetic resources (Wang et al., 2009).

The objective of this study is to determine the similarity of six natural Coelogyne spp species based on qualitative morphological characters for selecting the prospective parents of crossing.

\section{MATERIALS AND METHODS}

\section{Materials}

The materials used in this study were 6 Coelogyne spp (Table 1 and Figure 1) which is collection from Bogor Botanical Garden.

\section{Method}

The research was carried out by direct morphological observation and documenting plant parts from 6 Coelogyne species. Characterization was carried out on the stem, leaves, flowers and roots covering 30 characters using the scoring as done by Balithi, 2007.

\section{Statistical analysis}

Data analysis was performed using morphological data scoring from description to binary data. Morphological characters are analyzed by marking there (1) or none (0) for each character produced.

The data obtained were analyzed with the NTSYS-PC (Numerical Taxonomy and Multivariative Analysis System) version 2:02 Unweight pair group method with arithmetic method (UPGMA) function SIMQUAL (Qualitative Similarity) and utilized to obtain the genetic similarity matrix using Dice coefficient (Rohlf (1998)), the UPGMA (Unweighted Pair Group Method using Arithmetic Average) clustering method was used to contruct a dendrogram.

\section{RESULT AND DISCUSSION}

Morphological characterization of six Coelogyne species, C. pandurata, C. massangeana, C. mayeriana, C. asperata, C. celebensis and C. rumphii covering 30 characters (Balithi, 2007) is presented in the Table 2.

The similarity values based on morphlogical markers among the six Coelogyne orchids are presented in the matrix in Table 3. The matrix shows that the similarity values between Coelogyne orchids ranged from 0.670.87 . The similarity in morphological characteristics between large species reflects the similarity of genetic relationship between one species and the other. The similarity value of 0.87 is found between $C$. pandurata and $C$. rumphii. and C. mayeriana with C.asperata. Because in this study the target of selecting parents who have genetic similarity is $C$. pandurata as the parent possessing genetic closeness is $C$. rumphii. and $C$. mayeriana with $C$. asperata.

From the characters observed there were differences in morphological properties, namely the flower $C$. pandurata in green with black tongue petal (crown) shape ovate, the number of leaves in the two medium bulb $C$. rumphii yellow tongue brown petal shape straight, the number of leaves on the bulb one.

C. mayeriana has symmetry leaves, curvature lip at the base, longitudinal cross section shape pseudobulb and moderate size pseudobulb. While C. asperata has no asymmetry leaves, curves lip in the middle, longitudinal

Table 1: Plant materials and the origin

\begin{tabular}{|c|c|c|c|}
\hline No & Species & Locality and Habitat & Altitude (m) \\
\hline 1 & Coelogyne pandurata & East Kalimantan & 100 \\
\hline 2 & Coelogyne masangeana & West Sumatra & $1150-2100$ \\
\hline 3 & Coelogyne mayeriana & Kalimantan & 100 \\
\hline 4 & Coelogyne asperata & WestKalimantan & $320-\mathrm{I} 000$ \\
\hline 5 & Coelogyne celebensis & South Sulawesi & $826-220$ \\
\hline 6 & Coelogyne rumphii & South Sulawesi & $100-2000$ \\
\hline
\end{tabular}

Rev. Ceres, Viçosa, v. 66, n.4, p. 265-270, jul/aug, 2019 

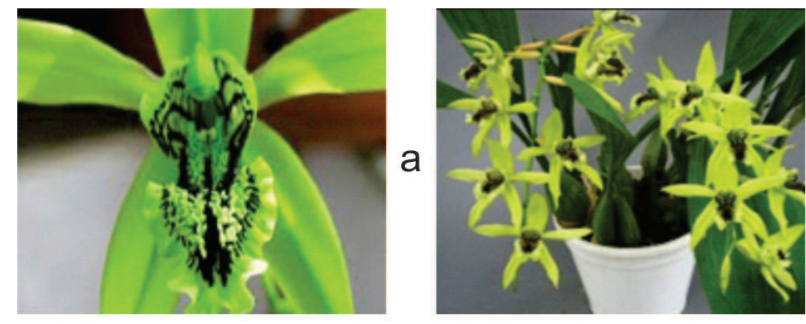

C. pandurata


C. massangeana
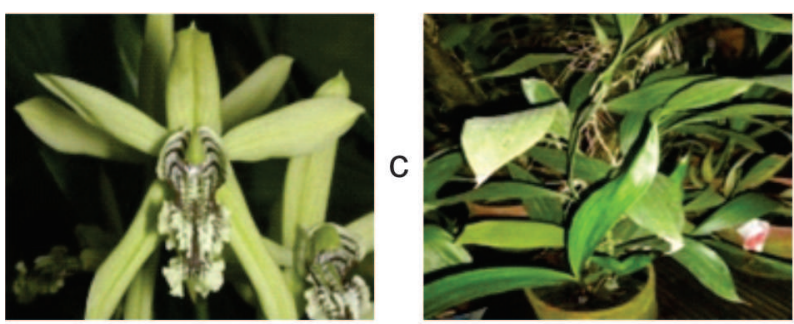

C. mayeriana
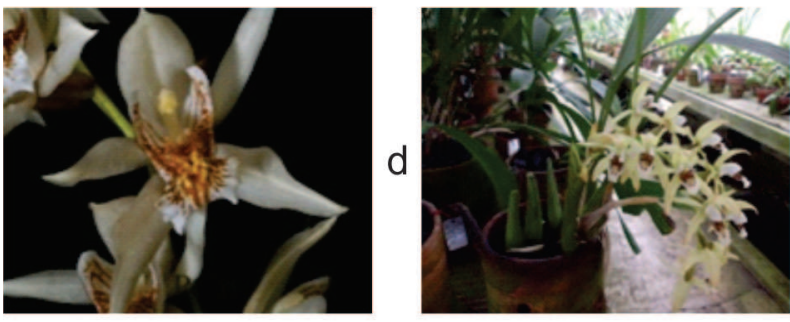

C. asperata
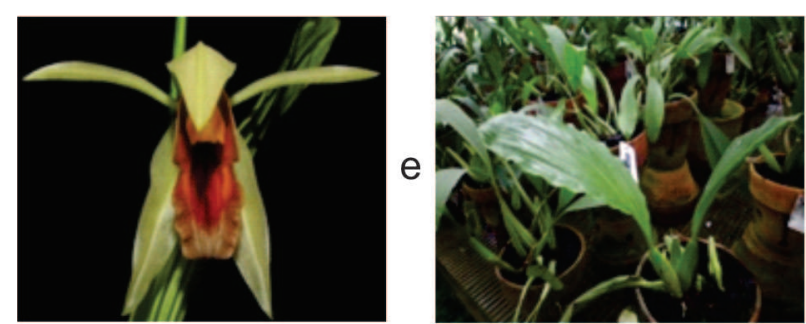

C. celebensis
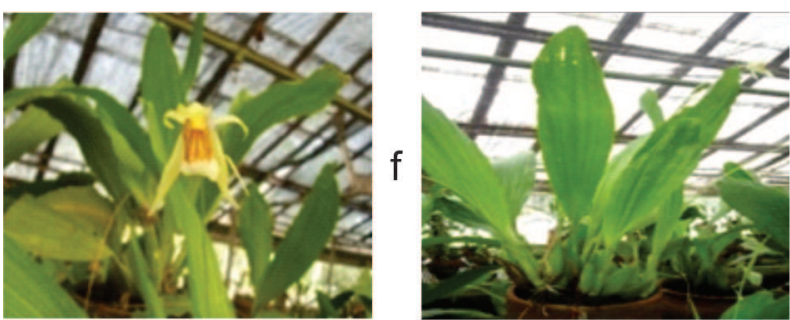

C. rumphii

Figure 1: Morphological orchid Coelogyne spp: a. C. pandurata b. C. massangeana c. C. mayeriana d. C. asperata e. C. celebensis, f. C. rumphii (Bogor botanical garden Indonesia, 2012). shape of eye javelin pseudobulb and large size pseudobulb. Pseudobulb has an important role as a storage medium for water, carbohydrates and minerals in orchid (Yang et al., 2016).

The dendrogram of Coelogyne spp based on morphology characters is presented in the Figure 2. The dendrogram shows similarities among the six orchids are between $70 \%-87 \%$. Therefore the genetic diversity among the six Coelogyne spp ranges from 13\% -30\%. From the six Coelogyne species in the similarity of 0.73 produces three groups, the first group consists of $C$. rumphii, and $C$. pandurata, the second group was $C$. massangeana, C. mayeriana and $C$. asperata while the third group consists of $C$. celebensis. This is in accordance with the study of Maiti et al. (2009) and Khosravi et al. (2009) who stated that orchid plants are flowering plants that have a high diversity pattern. While the previous study of Hartati \& Darsana (2015) show that there are morphological similarities in several genera of orchids from $50-100 \%$.

Since the closer the parent's genetic relationship the greater the chance of success in crossing (Purwantoro et al., 2006; Julisaniah et al., 2008; Xue et al. 2010), this study found that among the 6 species being studied, there are two pairs of parents that have most successful chance to be crossed, $C$. pandurata with $C$. rumphii and $C$. mayeriana with $C$. asperata.

The previous research showed that the dendrogram result indicated a considerable level of the molecular RAPD analysis showed six species forming three clusters with $46 \%$ similarity level. First cluster are $C$. pandurata, $C$. rumphii and $C$. celebensis. The second clusters are $C$. mayeriana and $C$. asperata the third cluster is $C$. massangeana.

The genetic range of six species from the Coelogyne genus is from 0.23-0.54 (Hartati et al., 2014). Another study identified the same 6 species of Coelogyne using molecular ISSR found that they had similarity coefficients ranging from 0.32 to 0.70 , meaning that the genetic diversity of the orchid species studied was spread between $30 \%$ to $68 \%$. Dendrogram shows that ten ISSR molecular markers are able to classify tree similarity clusters with a similarity coefficient of 0.51 . The first cluster consisted of $C$. pandurata, C. rumphii, C. mayeriana, C. asperata, the second cluster was $C$. celebensis and the third was $C$. massangeana (Hartati et al., 2017).

C. celebensis and C. rumphii, found in Peninsular Malaysia, Sumatra, Java, Kalimantan, Sulawesi and Maluku. All of these species have pseudobulb unifoliate except $C$. celebensis and C.asperata, which can also have two leafy pseudobulbs, another similarity supported by the subgroups of $C$. celebensis and C. rumphii, both of which have oval flower shield leaves. 


\begin{tabular}{|c|c|c|c|c|c|c|}
\hline \multirow{2}{*}{ Morphology } & \multicolumn{6}{|c|}{ Species } \\
\hline & C. pandurata & C. massangeana & C. mayeriana & C. asperata & C. celebensis & C. rumphii \\
\hline Growth type & sympodial & Sympodial & Sympodial & Sympodial & Sympodial & Sympodial \\
\hline Leaf shape & oblanceolate & oblanceolate & oblanceolate & oblanceolate & obovate & oblanceolate \\
\hline Leaf cross section & plicate & plicate & plicate & plicate & plicate & plicate \\
\hline Shape leaf tip & acute & acute & acuminate & acuminate & acuminate & acute \\
\hline Leaf edge shape & undulate & entire & entire & entire & sinuate & entire \\
\hline Leaf surface texture & glabrous & glabrous & glabrous & glabrous & glabrous & glabrous \\
\hline Leaf symmetry & Simetry & Simetry & Simetry & Not simetry & Simetry & Simetry \\
\hline Leaf color & Green & Green & Green & Green & Green & Green \\
\hline Flower shape & Star & Star & Star & Star & Star & Star \\
\hline Dorsal \& lateral sepal shape & lanceolate & oblong & lanceolate & lanceolate & lanceolate & lanceolate \\
\hline Petal shape & linear & linear & linear & linear & linear & linear \\
\hline Sepal \& petal tip shape & Acute & acuminate & acuminate & acuminate & acuminate & Acute \\
\hline Callus type on the lips & Simple & Simple & Simple & Simple & Complex & Complex \\
\hline Lip curvature & At the base & At the tip & At the base & at the middle & at the tip & at the base \\
\hline Murmur in the labellum & No murmur & No murmur & No murmur & No murmur & No murmur & No murmur \\
\hline Spur & No spur & No spur & No spur & No spur & No spur & No spur \\
\hline Flowering position & At the top/shoot & At the base & At the top/shoot & At the top/shoot & At the top/shoot & At the top/shoot \\
\hline Amount of pollinia & Four & Four & Four & Four & Four & Four \\
\hline Dorsal sepal color pattern & Prevalent & Prevalent & Prevalent & Prevalent & Prevalent & Prevalent \\
\hline Lateral sepal color pattern & Prevalent & Prevalent & Prevalent & Prevalent & Prevalent & Prevalent \\
\hline Petal color pattern & Prevalent & Prevalent & Prevalent & Prevalent & Prevalent & Prevalent \\
\hline Floral aroma & Smelling & Smelling & Smelling & Smelling & Smelling & Smelling \\
\hline Pseudobulb longitude section & Circular & Linear & Elliptic & Lanceolate & Elliptic & Elliptic \\
\hline Pseudobulb cross section shape & Circular & Circular & Elliptic/ & Elliptic/ & Circular & Circular \\
\hline Rooting type & Sticky root & Sticky root & Sticky root & Sticky root & Sticky root & Sticky root \\
\hline Leaf arrangement & Convolate & Convolate & Convolate & Convolate & Convolate & Convolate \\
\hline Resupinate & No resupinate & Resupinate & Resupinate & Resupinate & Resupinate & No resupinate \\
\hline Transverse \& longitudinal shape of dorsal and petal & Concave & Concave & Convex & Convex & Concave & Concave \\
\hline Cross section of lip & $\begin{array}{c}\text { Flips rather } \\
\text { deep }\end{array}$ & $\begin{array}{c}\text { Flips out with } \\
\text { a curved end }\end{array}$ & $\begin{array}{c}\text { Flips out with } \\
\text { a curved end }\end{array}$ & $\begin{array}{c}\text { Flips out with } \\
\text { a curved end }\end{array}$ & $\begin{array}{c}\text { Curved inward with } \\
\text { a flipped tip }\end{array}$ & Flips deeply \\
\hline Pseudobulb size & Large & Medium & Medium & Large & Medium & Large \\
\hline
\end{tabular}


Table 3: Similarity matrix based on morphological markers

\begin{tabular}{lllllll}
\hline & $\mathbf{1}$ & $\mathbf{2}$ & $\mathbf{3}$ & $\mathbf{4}$ & $\mathbf{5}$ & $\mathbf{6}$ \\
\hline 1 & 1.00 & & & & & \\
\hline 3 & 0.70 & 1.00 & & & & \\
\hline 4 & 0.70 & 0.77 & 1.00 & 1.00 & & \\
\hline 5 & 0.67 & 0.70 & 0.87 & 0.67 & 1.00 & 1.00 \\
\hline 6 & 0.67 & 0.73 & 0.77 & 0.67 & 0.73 & \\
\hline
\end{tabular}

\section{Note:}

$1=$ C. pandurata $; 2=$ C. Massangeana $; 3=$ C. Mayeriana $; 4=$ C. asperata

$5=$ C. Celebensis; $6=$ C. rumphii

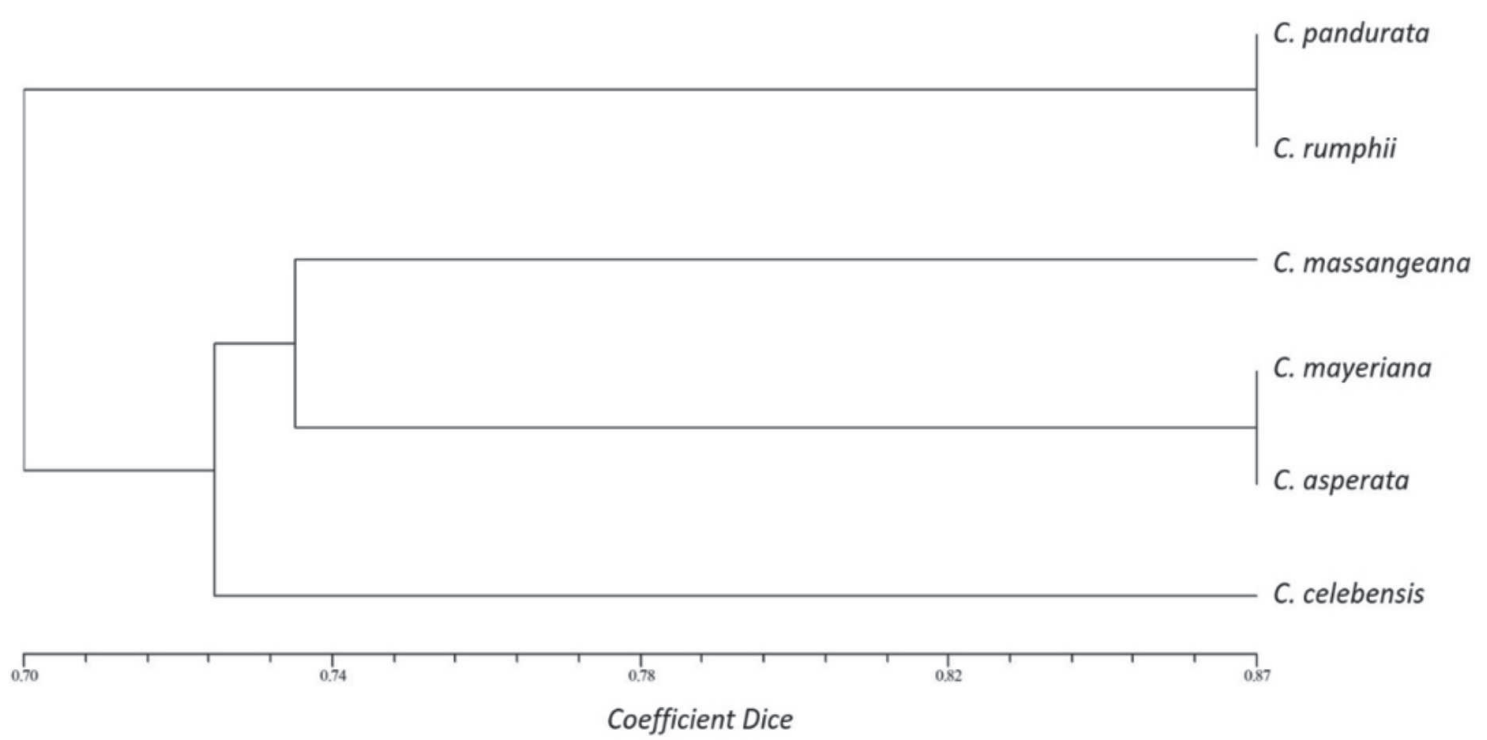

Figure 2: Dendrogram of Coelogyne spp based on morphology characters.

The results of this study show the difference with the results of the description carried out by Gravendeel \& Vogel, 2000 , namely the number of flowers on each stalk, the stem of the flower, the lower leaf, the blossom of the flower, the petals, the fruit, the lips, the third piece on the lips, the neck monument, stamens and stems that support the female and male genitals.

Clustering results of these six Coelogyne orchid species can be used as potential parents in more potential orchid assemblies. Lokho \& Kumar (2012) stated that characterization data is very useful for resource management and conservation of individual species but also for orchid breeders or farmers.

\section{CONCLUSION}

There is a morphological diversity among six natural Coelogyne spp in the characterization of stems, pseudobulb, leaves and flowers.

Based on the morphological similarity of $73 \%$, there are three groups were obtained, the first group consists of C. rumphii, and C. pandurata, the second group was $C$. massangeana, C. mayeriana and C. asperata and the third group was $C$. celebensis.

Based on the morphological similarity of $87 \%$ there are two pairs of parents that have most successful chance to be crossed, $C$. pandurata with $C$. rumphii and $C$. mayeriana with $C$. asperata.

\section{ACKNOWLEDGEMENTS, FINANCIAL SUPPORT AND FULL DISCLOSURE}

This work was financially supported by the Directorate Generale of Higher Education (DGHE), Ministry of Research, Technology and Higher Education of Indonesia, under the program of Penelitian Dasar Unggulan Perguruan Tinggi, 2018. We appreciate Yuniar at Bogor Botanical Garden. We guarantee that there is no conflict of interests in carrying the research and publishing the manuscript.

\section{REFERENCES}

Balithi (2007) Panduan karakteristik tanaman hias anggrek. Indonesia, Pusat Penelitian dan Pengembangan Hortikultura. Departemen Pertanian Republik Indonesia. 35p. 
Bhattacharyya P, Kumaria S \& Tandon P (2015) Applicability of ISSR and DAMD markers for phyto-molecular characterization and association with some important biochemical traits of Dendrobium nobile, an endangered medicinal orchid. Phytochemistry, 117:306-316.

Chase MW (2005) Classification of Orchidaceae in the age of DNA data. Curtis's Botanical Magazine, 22:02-07.

De LC, Rao AN, Rajeevan PK, Srivastava M \& Chhetri G (2015) Morphological characterization in Vanda species. International Journal of Scientific Research, 4:26-32.

Freudenstein JV dan Chase MW (2015) Phylogenetic relationships in Epidendroideae (Orchidaceae), one of the great flowering plant radiations: progressive specialization and diversification. Annals of Botany, 115:665-681.

Gravendeel B \& Vogel EF (2000) Total Evidence Phylogeny of Coelogyne and Allied Genera (Coelogininae, Epidendrodidae, Orchidaceae) Based on Morphologycal, Anatomical and Moleculer Characters. In: Gravendeel B (Ed.) Reorganising the Orchid genus Coelogyne. Nederland, Universiteit Leiden Branch. p. 37-56.

Hartati S \& Darsana L (2015) Karakterisasi anggrek alam secara morfologi dalam rangka pelestarian plasma nutfah. Jurnal Agronomi Indonesia, 43:133-139.

Hartati S, Nandariyah, Yunus A \& Djoar DW (2014) Genetic diversity of orchid Coelogyne spp by molecular RAPD (Random Amplified Polymorphic DNA) markers. International Journal of Applied Agricultural Research, 9:147-154.

Hartati S, Nandariyah N, Yunus A \& Djoar DW (2017) Short Communication: Cytological studies on black orchid hybrid (Coelogyne pandurata Lindley). Biodiversitas, 18:555-559.

Hartati S (2017) Study of Genetic Diversity on Six Species of Indonesian Coelogyne spp. Based on ISSR Markers. Pakistan Journal of Biological Sciences, 20:577-583

Julisaniah NI, Sulistyowati L \& dan Sugiharto AN (2008) Analisis Kekerabatan Mentimun (Cucumis sativus L.) menggunakan Metode RAPD - PCR dan Isozim. Jurnal Biodiversitas, 9:99102 .

Kartikaningrum S, Hermiati N, Baihaki A, Murdaningsih Haeruman K \& Mathius NT (2002) Kekerabatan Antar Genus Anggrek SubTribe Sarcanthinae Berdasarkan Data Fenotip dan Pola Pita DNA. Zuriat, XIII:01-10.

Khosravi AR, Kadir MA, Kadzemin SB, Zaman FQ \& and De Silva AE (2009) RAPD Analysis Of Cholchicine Induced Variation of The Dendrobium Serdang Beauty. Africa Journal of Biotechnology, 8:1455-1465.

Kuehnle AR (2007) Orchids, Dendrobium. In: Anderson NO (Ed.) Flower breeding and genetics. San Luis Obispo, Springer. p.539560 .
Lokho A \& Kumar Y (2012) Reproductive Phenology and Morphological Analysis of Indian Dendrobium Sw. (Orchidaceae) from the Northeast Region. International Journal of Scientific and Research Publications, 2:01-14.

Luo J, Hou BW, Niu ZT, Liu W, Xue QY \& Ding XY (2014) Comparative chloroplast genomes of photosynthetic orchids: Insights into evolution of the Orchidaceae and development of molecular markers for phylogenetic applications. PLoS ONE 9:e99016.

Maiti B, Shekar M, Khusiramani R \& Kasunasagar I (2009) Evaluation Of RAPD-PCR And Protein Profile Analysis To Differentiate Vibrio harveyi Strains Prevalent Along The Southwest Coast Of India. Journal of Genetics, 88:273-279.

Nandariyah (2010) Morphology and RAPD (Random Amplification of Polymorphic DNA) based classification of genetic variability of Java Salacca (Salacca zalacca Gaertner. Voss). Journal of Biotechnology and Biodiversity, 1:08-13.

Pangestu F, Aziz SA \& Sukma D (2014) Karakterisasi Morfologi Anggrek Phalaenopsis Hibrida. Jurnal Hortikultura Indonesia, 5:29-35

Purwantoro A, Ambarwati E \& Setyaningsih F (2006) Kekerabatan Antar Anggrek Spesies Berdasarkan Sifat Morfologi Tanaman Dan Bunga. Phylogenetic Of Orchids Based On Morphological Characters. Ilmu Pertanian, 12:01-11.

Rahayu SE \& Handayani (2008) Keanekaragaman Morfologi dan Ana- tomi Pandanus (Pandanaceae) di Jawa Barat. Vis Vitalis, $1: 29-44$.

Rohlf (1998) NTSYS-pc. Numerical Taxonomy and Multivariate Analysis System. Version 2,02. New York, Exerter software.

Wang HZ, Feng S, Lu J, Shi N \& Liu J (2009) Phylogenetic study and molecular identification of 31 Dendrobium species using inter-simple sequence repeat (ISSR) markers. Scientia Horticulturae, 8:01-08.

Xu, Yu \& Kumar (2010) Characterization of floral organ identity genes of Orchid Dendrobium crumenantum. Journal Moleculer Biology Biotechnology, 8:185-187.

Xue D, Feng S, Zhao H, Jiang H, Shen B, Shi N, Lu J, Liu J \& Wang H (2010) The linkage maps of Dendrobium Species based on RAPD and SRAP marker. Journal of Genetic and Genomic, 37:197-204.

Yang SJ, Sun M, Yang QY, Ma RY, Zhang JL \& Zhang SB (2016) Two strategies by epiphytic orchids for maintaining water balance: thick cuticles in leaves and water storage in pseudobulbs. Annals of Botany Plants, 8:01-10. 